\title{
A Comparative Study of Financial \\ OPEN ACCESS \\ Volume: 7 \\ Literacy and Financial Needs of Unbanked and Under Banked Population
}

Issue: 2

Month: April

Year: 2019

ISSN: $2320-4168$

Received: 19.03.2019

Accepted: 30.03.2019

Published: 01.04.2019

Citation:

Stalin, D. C. "A

Comparative Study

of Financial Literacy

and Financial Needs of

Unbanked and Under

Banked Population."

Shanlax International

Journal of Commerce, vol. 7, no. 2, 2019, pp. 31-37.

DOI:

https://doi.org/10.34293/

commerce.v7i2.375

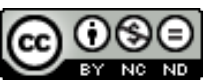

This work is licensed under a Creative Commons AttributionNonCommercialNoDerivatives 4.0 rnational License

\author{
D.C.Stalin \\ Assistant Professor in Finance and Accounts \\ University College, Sultanate of Oman, Oman
}

\begin{abstract}
This paper assumes an estimation of economical research of rapidly improving body on financial literacy. We begin with a synopsis of academic research, which emit financial learning as a structure interest in human capital. Development of financial learning has significant implication for benefit; also policies planned to increase levels of financial information in the well-built inhabitants. After that, we depict on topical surveys to ascertain how many numbers of people knows and categorize the least financial aptitude population subgroups. Though the narrative is still undeveloped, conclusions may perhaps strain on the subject of the effects and consequences of financial illiteracy, to work for answering these research gaps. A concluding part suggests a view on what remains to be educated, if researchers are to be improved to inform academic and experimental models with public policy.
\end{abstract}

Keywords: Financial Inclusion, Financial Knowledge, Financial Literacy, Household Financial Planning.

\section{Introduction}

The term "financial literacy" refers to an individual set of skills and knowledge which allows them to make conversant and effectual decisions from an understanding of finances. OECD has defined financial literacy as 'A grouping of financial awareness, information, ability, approach and performance necessary to make resonance financial decisions and ultimately achieve individual financial security. 'Also financial inclusion relates exclusively to awareness, access and utilizing of financial products. Consistent with OECD, 'Financial inclusion refers to the process of promote affordable, timely and ample access to a large collection of synchronized financial products and services and enlargement of their use by all segments of society through the performance of modified active and inventive approaches together with financial awareness and education with a view to promote financial security along with economic and social enclosure.' Financial inclusion and financial literacy are identical support. Whereas financial inclusion perform from supply part if the financial products and services for which the individuals insist, financial literacy inspire the insist side building conscious of the people for what they able to require (Subbarao, D., 2010). In the beginning level economies as India, that face the trouble of low level of literacy, poor convenience and low stipulate. The strength of the financial schemes in country desires the capability of its people to manage effectively their own finances. Over the ongoing years, financial literacy has suit a major area of anxiety in India. The general population at lack of information about financial issue anxious with routine capital management and saving for long period. The state of West Bengal in the eastern part of 
India has been chosen with the end goal of the investigation. One critical area of anxiety for West Bengal is the recurring financial forgeries which hit the state time and over again. The Sanchayita fraud in 1979 and frauds involving Sanchayani and Verona in the late 1980's were few previous examples. In 2013, the fall down of the Saradha Group (incorporated in 2008) bare a financial cheat with an approximate loss of Rs. 20000-30000 crores. News are extensive about groups like MPS, iCore, etc. residual unavailable in gathering currency from public at huge through comparable deposit plans. As well as reported in the news, people from rural and semi-urban areas, particularly including the daily wages and erstwhile engaged in the unordered labour market be mostly affected in the most recent rip-offs so far people from the town areas have remained elusive in hire the news and media persons know about their status in this admiration. Therefore, in the surroundings of the scams in West Bengal, a study into the position of financial literacy and its association with financial inclusion is mainly applicable.

\section{Notable Type of Financial Literacy}

- Financial literacy is anxious with financial information. It is a particular type of information about financial goods and services.

- Use of information financial literacy includes use of the financial knowledge which has gained. Financial literacy is gained from end to end down to earth involvement and dynamic mix of information. Information impacts behaviour or activity.

- Use of information budgetary education incorporates utilization of usage of the money related realizing which has picked up. Money related proficiency is Personal aptitude financial literacy is simply a own quality. It is the capacity to assess and make decisions on budgetary issues influencing everyday existence of an individual.

- A determinant of family unit prosperity. 21 Empirical investigations demonstrate that there is a solid connection among financial literacy and family unit prosperity.

- Individuals can't live without cash. Hard earned cash ought to successfully be used. Monetarily educated individual thinks well about dealing with his cash in order to make life smooth.
- Attitude of an individual about cash importantly affects his/her money related proficiency. Mentality towards cash, way of life, societal position, formal money related instruction and so forth impacts individual budgetary proficiency and in this way future prospects.

- Estimation of monetary education isn't basic as that of estimating general proficiency. The strategies for estimation varies as per the financial back ground of the general population whose money related education is considered, i.e., rich or poor either urban or country.

- All inclusiveness financial proficiency ideas are appropriate to all areas of the general public, moneyed or poor whichever in created or creating or immature countries.

\section{Objectives}

- To become more acquainted with bits of knowledge about significance of financial inclusion, reasons for financial exclusion. Its suggestions and appropriation of therapeutic key activities for financial related consideration in India.

- Review of writing on techniques for financial inclusion in India.

- To provide necessary suggestions to cover every Indian into formal banking system in Financial System and Financial Inclusion.

- To provide necessary suggestions to cover every Indian into formal banking system in Meaningful ways.

\section{Necessitate for Financial Inclusion in India}

- India should be cognizant on destitution mitigation, particularly among powerless groups

- Equitable economic development from side to side enhancements in jobs, better than average work openings, nourishment security.

- Financial Inclusive (FI) assembles reserve funds that advance economic development through beneficial venture.

- FI advances financial related proficiency of the provincial populace and henceforth directs them to keep away from the costly and temperamental financial services. 
- This encourages the more fragile segments to channelize their livelihoods into purchasing profitable assets or resources.

- In the circumstances of economic emergency, the provincial economy can be an emotionally supportive network to balance out the financial related framework. Thus, it helps in guaranteeing a maintainable financial structure.

- Financial consideration bolsters both economic proficiency and value and independence.
- Unrestrained access to open products and enterprises is a fundamental state of an open and effective society.

\section{Gender Wise Distribution of the Sample}

Table 1 shows $64 \%$ of entire respondents of Lohra community are males and 36\% are females. The respondents from Mahli society $52 \%$ are females and $48 \%$ are males. Datas collected from Bhutiyas society is include $56 \%$ males and $44 \%$ females.

Table 1

\begin{tabular}{|l|c|c|c|c|c|c|c|c|}
\hline Gender & Lohara & Lohara & Mahli & Mahli & Bhutiyas & Bhutiyas & Total & Total \\
\hline & Nos & $\%$ & Nos & $\%$ & Nos & $\%$ & Nos & $\%$ \\
\hline Male & 32 & 64.00 & 24 & 48.00 & 28 & 56.00 & 84 & 56.00 \\
\hline female & 18 & 36.00 & 26 & 52.00 & 22 & 44.00 & 66 & 44.00 \\
\hline TOTAL & $\mathbf{5 0}$ & $\mathbf{1 0 0 . 0 0}$ & $\mathbf{5 0}$ & $\mathbf{1 0 0 . 0 0}$ & $\mathbf{5 0}$ & $\mathbf{1 0 0 . 0 0}$ & $\mathbf{1 5 0}$ & $\mathbf{1 0 0 . 0 0}$ \\
\hline
\end{tabular}

\section{Age Wise Classification of the Sample}

Age wise classification of the respondents demonstrates that $42 \%$ of the all out respondents have a place with the age gathering of 25-55 years, $40 . \%$ have a place with the age gathering of Below 25 years and $32 \%$ have a place with the age gathering of 55 years and above. It very well may be noted from table. 2 that $8 \%$ of Lohara individuals, $64 \%$ of
Mahli people and $48 \%$ of Bhutiyas individuals have a place with the age gathering of Below 25 years. $36 \%$ of Lohara people, $20 \%$ of Mahli individuals and $28 \%$ of Bhutiyas individuals have a place with the age $25-55$ years. $56 \%$ of Lohara people, $16 \%$ of Mahli individuals and $24 \%$ of Bhutiyas individuals have a place with the age over 55 years.

Table 2

\begin{tabular}{|l|c|c|c|c|c|c|c|c|}
\hline \multirow{2}{*}{ Age in years } & \multicolumn{2}{|c|}{ Lohara } & \multicolumn{2}{c|}{ Mahli } & \multicolumn{2}{c|}{ Bhutiyas } & \multicolumn{2}{c|}{ Total } \\
\cline { 2 - 9 } & \multicolumn{2}{|c|}{ Nos \% } & \multicolumn{2}{c|}{ Nos \% } & \multicolumn{2}{c|}{ Nos \% } & \multicolumn{2}{c|}{ Nos \% } \\
\hline Below 25 & 4 & 08.00 & 32 & 64.00 & 24 & 48.00 & 60 & 40.00 \\
\hline $25-55$ & 18 & 36.00 & 10 & 20.00 & 14 & 28.00 & 42 & 28.00 \\
\hline 55 ABOVE & 28 & 56.00 & 8 & 16.00 & 12 & 24.00 & 48 & 32.00 \\
\hline \multicolumn{1}{|c|}{ TOTAL } & $\mathbf{5 0}$ & $\mathbf{1 0 0 . 0 0}$ & $\mathbf{5 0}$ & $\mathbf{1 0 0 . 0 0}$ & $\mathbf{5 0}$ & $\mathbf{1 0 0 . 0 0}$ & $\mathbf{1 5 0}$ & $\mathbf{1 0 0 . 0 0}$ \\
\hline
\end{tabular}

\section{Educational Qualification Wise Distribution of the Sample}

Table which given below shows the Educational Qualification distribution wise model. From the table $38.67 \%$ of the entire people have no proper education was observed. up to 5 th std, $16.00 \%$ of them are educated and people qualified from 5 th to 10 th std was around $34.67 \%$. People who were qualified up to degree from 10th std was $8.00 \%$ and Degree - UG, $2.66 \%$ of them belong to the education category.
From Lohra people 56.00\% and from Mahli people $60.00 \%$ of them have no proper education. But people belongs to Bhutiyas have sufficient financial facilities to acquire formal education. People educated up to 5thstd were $20.00 \%$ from Lohra people, $24.00 \%$ from Mahli people and $4.00 \%$ from Bhutiyas. people belong to the education category of 5th std-10thstd were $16.00 \%$ of Lohara people, $16.00 \%$ of Mahli people and $72.00 \%$ of Bhutiyas. From 10th std- Degree education categorized people of Bhutiyas were $24 \%$ and there is no Lohara and 
Mahli people belong to this category. There is no Mahli and Bhutiya people belong to this category and only $8 \%$ of Lohara people belong to the education category of Degree - PG.

Table 3

\begin{tabular}{|l|c|c|c|c|c|c|c|c|}
\hline \multirow{2}{*}{ Qualification } & \multicolumn{2}{|c|}{ Lohara } & \multicolumn{2}{c|}{ Mahli } & \multicolumn{2}{c|}{ Bhutiyas } & \multicolumn{2}{c|}{ Total } \\
\cline { 2 - 9 } & \multicolumn{2}{|c|}{ Nos \% } & \multicolumn{2}{c|}{ Nos \% } & \multicolumn{2}{c|}{ Nos \% } & \multicolumn{2}{c|}{ Nos \% } \\
\hline No Education & 28 & $56.00 \%$ & 30 & $60.00 \%$ & 0 & 00.00 & 58 & $38.67 \%$ \\
\hline Upto 5th Std & 10 & $20.00 \%$ & 12 & $24.00 \%$ & 2 & $4.00 \%$ & 24 & $16.00 \%$ \\
\hline 5 - 10th Std & 8 & $16.00 \%$ & 8 & $16.00 \%$ & 36 & $72.00 \%$ & 52 & $34.67 \%$ \\
\hline 10th - Degree & 0 & 00.00 & 0 & 00.00 & 12 & $24 \%$ & 12 & $8.00 \%$ \\
\hline Degree-UG & 4 & $8 \%$ & 0 & 00.00 & 0 & 00.00 & 4 & $2.66 \%$ \\
\hline \multicolumn{1}{|c|}{ TOTAL } & $\mathbf{5 0}$ & $\mathbf{1 0 0 . 0 0}$ & $\mathbf{5 0}$ & $\mathbf{1 0 0 . 0 0}$ & $\mathbf{5 0}$ & $\mathbf{1 0 0 . 0 0}$ & $\mathbf{1 5 0}$ & $\mathbf{1 0 0 . 0 0}$ \\
\hline
\end{tabular}

\section{Occupation Wise Distribution of the Sample}

Table. 4 describes as $77.33 \%$ of the total respondents are daily wage earners, which are observed by the occupation wise classification. From the total percentage of people $01.33 \%$ have Public job. $14.67 \%$ of the people have private job and $6.67 \%$ of them not having any other job which includes students, house wives and other persons. $84.00 \%$ of Lohara people, $92.00 \%$ of Mahli people and $56.00 \%$ of Bhutiyas people are daily wage earners. $4 \%$ of Lohara have public job and Mahli and Bhutiyas have no public jobs. $12.00 \%$ of Lohara people, $4 \%$ of Mahli people and $24.00 \%$ of Bhutiyas people have private job. $4.00 \%$ of the respondents of Mahli community and $16.00 \%$ Bhutiyas community do not have any job.

Table 4

\begin{tabular}{|l|c|c|c|c|c|c|c|c|}
\hline \multirow{2}{*}{ Occupation } & \multicolumn{2}{|c|}{ Lohara } & \multicolumn{2}{c|}{ Mahli } & \multicolumn{2}{c|}{ Bhutiyas } & \multicolumn{2}{c|}{ Total } \\
\cline { 2 - 9 } & \multicolumn{2}{|c|}{ Nos \% } & \multicolumn{2}{c|}{ Nos \% } & \multicolumn{2}{c|}{ Nos \% } & \multicolumn{2}{c|}{ Nos \% } \\
\hline Daily Wage & 42 & 84.00 & 46 & 92.00 & 28 & 56.00 & 116 & 77.33 \\
\hline Public Job & 2 & 04.00 & 0 & 00.00 & 0 & 00.00 & 2 & 01.33 \\
\hline Private Job & 6 & 12.00 & 2 & 04.00 & 14 & 28.00 & 22 & 14.67 \\
\hline No Job & 0 & 00.00 & 2 & 04.00 & 8 & 16.00 & 10 & 06.67 \\
\hline \multicolumn{1}{|c|}{ TOTAL } & $\mathbf{5 0}$ & $\mathbf{1 0 0}$ & $\mathbf{5 0}$ & $\mathbf{1 0 0}$ & $\mathbf{5 0}$ & $\mathbf{1 0 0}$ & $\mathbf{1 5 0}$ & $\mathbf{1 0 0}$ \\
\hline
\end{tabular}

\section{Level of Financial Inclusion}

In the present examination the dimension of financial inclusion is determined based on the utilization of financial services by the respondents. On the off chance that they are utilizing any of the financial services, for example, Bank, Insurance, Mutual Funds, SHG, Pension Funds, Financial Market, Post Office Deposits and Non Banking Financial Services, they are treated as monetarily included and on the off chance that they are not utilizing any of the money related administrations, they are treated as financially excluded. The after effect of the investigation is exhibited in table 5. It very well may be seen from the table that $93.33 \%$ of the complete respondents are financially included and the staying $6.67 \%$ of them are financially excluded. When taking a gander at the network savvy examination, it very well may be noticed that allrespondents of Bhutiyas people group are financially included. The dimension of financial inclusion is $92.00 \%$ among Lohara people group and $88.00 \%$ among Mahli people group. So the dimension of money related consideration is higher among Bhutiyas individuals and lower among Mahli individuals. 
Table 5

\begin{tabular}{|c|c|c|c|c|c|c|c|c|}
\hline \multirow{2}{*}{$\begin{array}{c}\text { Level of financial } \\
\text { inclusion }\end{array}$} & \multicolumn{2}{|c|}{ Lohara } & \multicolumn{2}{c|}{ Mahli } & \multicolumn{2}{c|}{ Bhutiyas } & \multicolumn{3}{c|}{ Total } \\
\cline { 2 - 10 } & \multicolumn{2}{|c|}{ Nos \% } & \multicolumn{2}{c|}{ Nos \% } & \multicolumn{2}{|c|}{ Nos \% } & \multicolumn{2}{c|}{ Nos \% } \\
\hline Financially Included & 46 & 92.00 & 44 & 88.00 & 50 & 100.00 & 140 & 93.33 \\
\hline Financially excluded & 4 & 08.00 & 6 & 12.00 & 0 & 00.00 & 10 & 6.67 \\
\hline TOTAL & $\mathbf{5 0}$ & $\mathbf{1 0 0}$ & $\mathbf{5 0}$ & $\mathbf{1 0 0}$ & $\mathbf{5 0}$ & $\mathbf{1 0 0}$ & $\mathbf{1 5 0}$ & $\mathbf{1 0 0}$ \\
\hline
\end{tabular}

\section{Level of Usage of Various Financial Services}

Table 6 demonstrates the dimension of use of different financial services by the respondents. It tends to be seen from the table that $90.66 \%$ of the absolute respondents are utilizing Banking offices, 40.66\% are partner with Self Help Groups, 33.33\% of them have Insurance inclusion, $36.00 \%$ of them are utilizing non banking financial services, $22.66 \%$ of them have post office investment funds, 9.33\% of them are partner with any of the pension funds and $5.33 \%$ of them are partner with money related markets. No respondents are utilizing the Mutual Fund plans. $92.00 \%$ of Lohara individuals, $84.00 \%$ of Mahli individuals and $96.00 \%$ of Bhutiyas individuals are utilizing Banking facilities. 52.00\% of Lohara individuals, $12.00 \%$ of Mahli individuals and $36.00 \%$ of Bhutiyas individuals have Insurance coverage. $80.00 \%$ of Lohara individuals, $36.00 \%$ of Mahli individuals and $12.00 \%$ of Bhutiyas individuals are partner with Self Help Groups. $16.00 \%$ of Lohara individuals are partner with any of the pension funds and $12.00 \%$ of them are partner with money related markets and $12.00 \%$ of Mahli people groups having their pension funds. In any case, no respondents from Bhutiyas people group approach benefits plans and money related markets. $28.00 \%$ of Lohara individuals, $12.00 \%$ of Mahli individuals and $28.00 \%$ of Bhutiyas individuals have post office deposits. $36.00 \%$ of Lohara individuals, $24.00 \%$ of Mahli individuals and $44.00 \%$ of Bhutiyas individuals are utilizing non banking financial services.

Table 6

\begin{tabular}{|l|c|c|c|c|c|c|c|c|}
\hline \multirow{2}{*}{ Various Financial Services } & \multicolumn{2}{|c|}{ Lohara } & \multicolumn{2}{c|}{ Mahli } & \multicolumn{2}{c|}{ Bhutiyas } & \multicolumn{2}{c|}{ Total } \\
\cline { 2 - 10 } & \multicolumn{2}{|c|}{ Nos \% } & \multicolumn{2}{c|}{ Nos \% } & \multicolumn{2}{c|}{ Nos \% } & \multicolumn{2}{c|}{ Nos \% } \\
\hline Banking & 46 & 92.00 & 42 & 84.00 & 48 & 96.00 & 136 & 90.666 \\
\hline Insurance Schemes & 26 & 52.00 & 6 & 12.00 & 18 & 36.00 & 50 & 33.333 \\
\hline Mutual Funds & 0 & 00.00 & 0 & 00.00 & 0 & 00.00 & 0 & 00.00 \\
\hline SHG & 40 & 80.00 & 18 & 36.00 & 6 & 12.00 & 64 & 40.66 \\
\hline Pension Schemes & 8 & 16.00 & 6 & 12.00 & 0. & 00.00 & 14 & 9.33 \\
\hline Financial market place & 6 & 12.00 & 2 & 04.00 & 0 & 00.00 & 8 & 5.33 \\
\hline Post office FD & 14 & 28.00 & 6 & 12.00 & 14 & 28.00 & 34 & 22.66 \\
\hline Non Banking Finacial services & 18 & 36.00 & 14 & 24.00 & 22 & 44.00 & 54 & 36.00 \\
\hline
\end{tabular}

\section{Level of Financial Literacy}

The dimension of financial literacy among the innate individuals is analysed with respect to various financial terms. Their level of consciousness is estimated dependent on three point scale, for example, high consciousness, normal consciousness and low consciousness. It tends to be seen from the exploration that no respondent have high consciousness as to different monetary terms. The respondents have normal consciousness about different budgetary terms, for example, Bank stores, Bank advances, ATM and Check. They have low consciousness about the rest of the terms. Their consciousness level is higher concerning the term 'Bank stores' and consciousness level is lower with respect to the term Stock market'. The outcomes exhibited in this paper uncover that there is noteworthy contrast in the education dimension of different tribal communities with respect to every financial terms. While taking a gander at the by and 
large financial literacy, the inborn individuals have a low dimension of financial literacy. Among the different tribal communities, Bhutiyas individuals have relatively higher proficiency pursued by Lohara individuals. The dimension of financial literacy is extremely low among Mahli individuals.

\section{Suggestions}

- Government organizations and NGOs may embrace financial awareness programs among the inborn individuals to build their financial literacy. That will be useful to bring a routine with regards to recording of wages and uses among them.

- Banks, Insurance organizations and other financial service providers may focus more on the ancestral individuals since they are not yet completely financially included. It will assist the offices with increasing their client base.

- Specialists may find a way to incorporate financial literacy education programs in the school educational modules. It will shape a financially educated new generation.

- While undertaking any inborn improvement programs, more focus might be given to Mahli people group since they are a long ways behind than other tribal communities definitely.

\section{Conclusion}

Financial literacy is considered as a noteworthy connection for advancing promoting financial inclusion and at last financial constancy. Along these lines, government experts are giving a lots consideration to financial literacy programmes. Anyway the issue is that, these programmes are not making any contact with an extensive area of the populace which is inside society and effectively in reverse. The present investigation uncovered that the ethnic individuals are deficiently educated about different financial products and arrangements. As financial illiteracy of education may abuse their fitness to spare and contribute for retirement, decay their security in prime of life, it is disturbing. In spite of the fact that it is happy to propose that different government conspire like NREG Program, Micro credit office and so on have slanted the ethnic individuals to a huge broaden. Normally the ethnic individuals incorporate bank account because of the reason that the payment under NREG Program is paid through the individual bank account of the beneficiaries of this plan.It shows that if a plan is fittingly presented, it will surely make a few required outcomes. Along these lines, the governmental organizations need to scene the financial literacy plan in such a technique to achieve the rural group of individuals.

\section{References}

Anita Gardeva \& Elisabeth Rhyne, Opportunities and Obstacles to Financial Inclusion, Published by Center for Financial Inclusion, New York, 2011.

ANZ Bank, ANZ Survey of Adult Financial Literacy in Australia, The Social Research Centre, Department of Financial Inclusion \& Capability, The Australia and New Zealand Banking Group Limited (ANZ), Australia, 2011.

Bo Carlsson, Innovation Systems: A Survey of the Literature from a Schumpeterian Perspective, Case Western Reserve University.

Campbell J Y, "Household finance," The Journal of Finance. vol. LXI, no. 4, 2006 August, pp. 15531604.

Hilgert M A, Hogarth J M \& Beverly S G, "Household financial management: The connection between knowledge and behavior," Federal Reserve Bulletin, vol. 89, no. 7, 2003 July, pp. 309-322.

Lusardi \& Mitchell O S, "Financial literacy around the world: An overview," Journal of Pension Economics and Finance, Cambridge University Press, vol. 10, no. 04, 2011, pp. 497-508.

Mahdzan N S \& Tabiani S, "The impact of financial literacy on individual saving: An exploratory study in the Malaysian context," Transformations in Business and Economics, vol. 12, no. 1 (28), 2013, pp. 41-55.

Memdani L \& Rajyalakshmi K, "Financial Inclusion in India," International Journal of Applied Research and Studies (iJARS) ISSN: 2278-9480 vol. 2, no. 8, August 2013.

Nash D R, "Financial literacy: An Indian scenario," Asian Journal of Research in Banking and Finance, vol. 2, no. 4, 2012 April, pp. 79-84. 
Wood Downer K, Lees B \& Toberman A, Household financial decision making: Qualitative research with couples, Department for Work and Pensions

Research Report no. 805, London: DWP. 2012.

\section{Author Detail \\ Dr.D.C.Stalin}

Assistant Professor in Finance and Accounts, University College, Sultanate of Oman, Oman.

Email ID:dcstn80@gmail.com 